\title{
PENGARUH KOMPETENSI, INDEPENDENSI DAN UKURAN AUDITEE TERHADAP KUALITAS AUDIT
}

\author{
Dwi Agustina $\mathrm{H}$ \\ Made Sudarna \\ Unti Ludigdo
}

Program Magister Akuntansi

Pasca Sarjana Fakultas Ekonomi dan Bisnis Universitas Brawijaya Malang, dan Staf BPK

Jl. Mayjen Haryono 165 Malang

Abstract

This study examines and analyzes the influence of competence, independence and the size of the auditees on audit quality. Audit quality is defined as the probability that the auditor will both discover and report a breach in the client's accounting system. Drivers of audit quality-a framework are : culture within the firm, the skills and personal qualities of audit partners and staff, the effectiveness of the audit process, the reliability and usefulness of audit reporting, factors outside the control of auditors. Competence of auditors is adequate professional proficiency to perform inspection tasks and professional proficiency in the preparation of examination report. In this study, the competence dimension of competence using Certified General Accountant (CGA) are leadership, professionalism and professional knowledge. The independence is the mental attitude and appearance that is free from private interference, and external organizations. The independence consisting of: a long relationship with the auditees and the provision of non audit services and the pressure of the auditees, peer review of auditors. Auditee size is total assets and revenue of each county/city in Java. Using the random sampling method, the research tries to collect some inportant information given by respondents. Questionaire is a tool used to measure the variables. The hypotheses were tested with SPSS. The sample of this study is the Chairman of the audit team LKPD 2010 on the BPK RI in Java. Data obtained by spreading 118 and a 
total of 110 questionnaires are returned and processed feasible. The results partially demonstrate competence and independence affect audit quality, while the size of the auditee does not affect audit quality. Researchers can then add other indicators in the variable size of auditees such as number of population and area, total spending, the number of programs and activities within one year.

Keywords: audit quality, competence, independence and the size of the auditees

Abstrak

Penelitian ini menguji dan menganalisis pengaruh kompetensi, independensi dan ukuran auditee terhadap kualitas audit. Kualitas audit merupakan kemungkinan auditor dapat mendeteksi adanya kecurangan dalam sistem akuntansi klien dan melaporkan kecurangan tersebut. Kerangka kerja kualitas audit terdiri dari dimensi lingkungan organisasi, kemampuan/ keahlian staf auditor dan partner, efektivitas dari proses audit, laporan audit yang dapat diandalkan dan bermanfaat, faktor diluar kendali auditor. Kompetensi auditor adalah kecakapan profesional yang memadai untuk melaksanakan tugas pemeriksaan dan kemahiran profesional dalam penyusunan laporan hasil pemeriksaan. Dalam penelitian ini, kompetensi menggunakan dimensi kompetensi dari Certified General Accountant (CGA) yaitu kepemimpinan, profesionalisme dan professional knowledge. Independensi adalah sikap mental dan penampilan yang bebas dari gangguan pribadi, ekstern dan organisasi, terdiri dari: lama hubungan dengan auditee dan pemberian jasa non audit dan tekanan dari auditee, telaah dari rekan auditor. Ukuran auditee adalah total aset dan pendapatan asli daerah masing-masing kabupaten/ kota di Jawa. Sampling menggunakan metode random, Jenis data yang digunakan adalah data primer. Kuesioner digunakan sebagai alat untuk mengukur variabel yang diuji. Pengujian hipotesis dilakukan dengan menggunakan bantuan program SPSS. Sampel penelitian ini adalah Ketua Tim audit LKPD TA 2010 pada kantor BPK RI Perwakilan di Jawa. Data diperoleh dengan menyebarkan 118 kuesioner dan sebanyak 110 yang kembali dan layak diolah. Hasil penelitian secara parsial menunjukkan kompetensi dan independensi mempengaruhi kualitas audit, sedangkan ukuran auditee tidak mempengaruhi kualitas audit. Peneliti selanjutnya dapat menambahkan indikator lain dalam variabel ukuran auditee misalnya jumlah penduduk dan luas wilayah, total belanja, jumlah program dan kegiatan dalam satu tahun.

Kata kunci: kualitas audit, kompetensi, independensi dan ukuran auditee

\section{PENDAHULUAN}

Tingginya kebutuhan akan jasa audit membuat profesi auditor juga berkembang mengikuti perkembangan dunia bisnis. Para stakeholders menggunakan informasi 
keuangan yang telah diaudit sesuai posisi dan kepentingan masing-masing dalam mengambil keputusan. Untuk itu integritas dan profesionalisme auditor menjadi jaminan kepercayaan publik yang secara langsung akan berdampak pada profesi audit. Tanggungjawab auditor menurut SAS No. 53 tentang The auditor's responsibility to detect and report errors and irregularities, adalah mendeteksi dan melaporkan adanya kesalahan dan ketidakberesan. Standar Profesional Akuntan Publik (SPAP) menyebutkan profesi auditor independen memiliki tanggungjawab moral, profesional dan hukum. Sesuai dengan tanggungjawabnya, diharapkan profesi auditor dapat menunjukkan kinerja dan hasil audit yang dapat dimanfaatkan oleh stakeholders. Hasil pekerjaan audit yang baik menunjukkan kualitas audit yang baik pula. Kualitas audit menurut De Angelo (1981) adalah probabilitas seorang auditor dapat menemukan dan melaporkan suatu penyelewengan dalam sistem akuntansi klien. Maradona, Sutrisno dan Chandrarin juga menyebutkan konsep kualitas audit dalam A Statement of Basic Auditing Concepts (AAA, 1973:13) yaitu auditor harus mampu untuk melakukan pengendalian atas kualitas informasi keuangan yang disajikan oleh suatu perusahaan dengan cara memastikan kesesuaiannya dengan prinsip akuntansi berterima umum.

Kualitas audit ini penting karena dengan kualitas audit yang tinggi maka akan dihasilkan laporan keuangan yang dapat dipercaya sebagai dasar pengambilan keputusan pengguna laporan keuangan. Kualitas audit saat ini banyak mendapat sorotan masyarakat terutama kualitas audit sektor publik. Saat ini telah muncul beberapa kasus suap auditor BPK. Diantaranya adalah kasus suap oleh oknum pejabat Pemerintah Kota Bekasi terhadap dua pemeriksa BPK agar laporan keuangan Bekasi tahun 2009 menjadi Wajar Tanpa Pengecualian (Detiknews.com, 2010). KPK juga menemukan indikasi dugaan suap Walikota Tomohon terhadap auditor Badan Pemeriksa Keuangan (BPK) agar opini hasil audit laporan keuangan Pemerintah Kota Tomohon tahun 2009 wajar tanpa pengecualian (WTP) (Inilah.com, 2010). Dengan adanya beberapa kasus tersebut, kepercayaan masyarakat atas kualitas audit sektor publik dapat menurun.

Profesi akuntan publik mempunyai dua sisi. Di satu sisi auditor harus memperhatikan kredibilitas dan etika profesi, namun di sisi lain auditor juga harus menghadapi tekanan dari klien dalam berbagai pengambilan keputusan. Jika auditor tidak mampu menolak tekanan dari klien seperti tekanan personal, emosional atau keuangan maka independensi auditor telah berkurang dan dapat mempengaruhi kualitas audit. Salah satu faktor lain yang mempengaruhi independensi tersebut adalah jangka waktu di mana auditor memberikan jasa kepada klien (auditor tenure). Untuk meningkatkan kepercayaan masyarakat terhadap independensi auditor maka pekerjaan akuntan dan operasi Kantor Akuntan Publik (KAP) perlu dimonitor dan di "audit" oleh sesama auditor (peer review) guna menilai kelayakan desain sistem pengendalian kualitas dan kesesuaiannya dengan standar kualitas yang disyaratkan. De Angelo (1981) mengatakan bahwa kualitas audit tergantung pada 2 faktor, 
yaitu: (1) kemampuan auditor untuk menguji akun-akun dan mengidentifikasi kesalahan atau anomali melalui kompetensi teknisnya; dan (2) objektivitas melalui independensinya. Oleh karena itu De Angelo (1981) mendefinisikan kualitas audit sebagai kemungkinan auditor dapat mendeteksi dan melaporkan kesalahan atau kecurangan dalam sistem informasi akuntansi klien.

Kualitas audit juga dipengaruhi oleh independensi. Menurut Mautz dan Sharaf (1961:204) Independensi tidak hanya menekankan pada nilai penting dari independensi terhadap pengauditan, tetapi juga dari sisi tampilan dan kenyataan (in appearance and in fact). Mautz dan Sharaf (1961)berpendapat ada dua aspek dari independensi, yaitu (1) independensi real dari seorang praktisi dalam melaksanakan pekerjaannya dan (2) independensi dalam penampilan dari auditor sebagai satu kelompok profesional. Mereka menyebutnya sebagai "independensi praktisi" dan independensi profesi". Independensi praktisi berhubungan dengan kemampuan praktisi individual untuk mempertahankan perilaku yang tepat/pantas di dalam perencanaan program auditnya, mempertahankan kinerjanya ketika melakukan pemverifikasian, dan menyiapkan laporan. Sebaliknya,independensi profesi berhubungan dengan citra auditor sebagai sebuah kelompok. Mautz dan Sharaf (1961:206-207) mengusulkan tiga dimensi independensi auditor. Pertama adalah independensi dari kontrol atau pengaruh yang tidak diinginkan dalam pemilihan teknik dan prosedur audit dan luas penerapannya. Kedua adalah independensi dari kontrol atau pengaruh yang tidak diinginkan dalam pemilihan area, aktivitas, hubungan personal, dankebijakan manajerial yang ingin diuji. Terakhir adalah independensi dari kontrol atau pengaruh yang tidak diharapkan dalam penyampaian fakta yang ditemukan dari pengujian atau dalam penyampaian rekomendasi atau opini sebagai hasil dari sebuah pengujian.

Penelitian ini merupakan pengembangan dari penelitian yang telah dilakukan oleh Putri (2010) yang menguji pengaruh kompetensi terhadap kualitas audit laporan keuangan; pengaruh independensi terhadap kualitas audit (Shockley, 1981 dan Deis dan Giroux, 1992); serta pengaruh ukuran auditee terhadap kualitas audit (Deis dan Giroux, 1992 dan Carcello, dkk., 2004). Kualitas audit dikembangkan dari UK Financial Reporting Council (FRC) dalam Holt (2007) dan Putri (2010) meliputi budaya perusahaan, kemampuan/keahlian, kualitas partner dan staf auditor, laporan audit yang dapat diandalkan dan bermanfaat dan faktor diluar kendali auditor. Kompetensi menggunakan dimensi dari CGA dalam penelitian Seema Sanghi (2007) dalam Putri (2010) yaitu kepemimpinan, profesionalisme dan professional knowledge. Sedangkan dimensi independensi dikembangkan dari lama hubungan dengan auditee dan pemberian jasa non audit (Shockley,1981) dan tekanan dari auditee, telaah dari rekan auditor (Deis dan Giroux, 1992). Dimensi ukuran auditee dikembangkan dari penelitian Deis dan Giroux (1992) dan Carcello dkk. (2004) diukur dari Pendapatan Asli Daerah dan besarnya total aset auditee. Perbedaan penelitian ini dengan penelitian sebelumnya adalah penelitian ini dilakukan pada sektor publik yaitu auditor pemerintah serta ukuran auditee yang merupakan entitas pemerintahan. 


\section{Rumusan Masalah}

Dari latar belakang masalah yang diuraikan di atas, dapat dirumuskan masalah dalam penelitian ini yaitu: Apakah kompetensi, independensi dan ukuran auditee menentukan kualitas audit pada sektor publik?

\section{KAJIAN TEORI}

\section{Kualitas Audit Laporan Keuangan}

De Angelo (1981) mendefinisikan kualitas audit (Audit Quality) sebagai peluang seorang auditor menemukan dan melaporkan tentang adanya suatu pelanggaran dalam sistem akuntansi kliennya. Hasil penelitiannya menunjukkan bahwa KAP yang besar akan berusaha untuk menyajikan kualitas audit yang lebih besar dibandingkan dengan KAP yang kecil. Kualitas audit berdasarkan Standar Profesional Akuntan Publik (SPAP) dan Standar Pemeriksaan Keuangan Negara (SPKN), audit yang dilaksanakan auditor tersebut dapat berkualitas jika memenuhi ketentuan atau standar auditing. Standar auditing mencakup mutu profesional (professional qualities) auditor independen, pertimbangan (judgment) yang digunakan dalam pelaksanaan audit dan penyusunan laporan auditor. Standar auditing tersebut meliputi standar umum, standar pelaksanaan pekerjaan lapangan dan standar pelaporan.

\section{Kompetensi Auditor}

Penelitian Bonner (1990) menunjukkan pengetahuan mengenai tugas spesifik membantu kinerja auditor berpengalaman melalui komponen pemilihan dan pembobotan bukti hanya pada saat penetapan resiko analitis. Pengaruh akuntabilitas terhadap kinerja auditor dilakukan oleh Tan dkk.(1999) dimana hasilnya menunjukkan akuntabilitas akan meningkatkan kinerja ketika pengetahuan dan kemampuan memecahkan masalah yang tinggi. Ashton (1991) dalam Alim (2007) menunjukkan pengetahuan spesifik dan lama pengalaman bekerja sebagai faktor penting dalam meningkatkan kompetensi. De Angelo (1881) dan Alim dkk. (2007) menggunakan pengalaman dan pengetahuan sebagai proksi kompetensi.

\section{Independensi Auditor}

Independensi suatu standar auditing yang penting karena opini akuntan independen bertujuan untuk menambah kredibilitas laporan keuangan yang disajikan oleh manajemen. Kode etik Akuntan tahun 2004 menyebutkan bahwa independensi adalah sikap yang diharapkan dari seorang akuntan publik untuk tidak mempunyai kepentingan pribadi dalam pelaksanaan tugasnya, yang bertentangan dengan prinsip integritas dan obyektivitas. Integritas merupakan prinsip moral yang tidak memihak, jujur, memandang dan mengemukakan fakta seperti apa adanya. Dilain pihak objektivitas merupakan sikap tidak memihak dalam mempertimbangkan fakta, kepentingan pribadi tidak terdapat dalam fakta yang dihadapi Mulyadi (1992) dalam Mayangsari (2003). 


\section{Ukuran Auditee}

Ukuran/kekayaan auditee dalam Deis dan Giroux (1992) diproksikan dengan nilai properti/kekayaan yang dimiliki auditor. Dalam penelitiannya tentang determinan dari kualitas audit oleh Independent CPA firm di Texas pada Audits of Independent School District, menyebutkan kekayaan atau kesehatan keuangan klien juga berkorelasi dengan kualitas audit. Klien lebih besar dan sehat secara finansial menerima audit mutu lebih rendah. Carcello, $d k k$. (2004) menunjukkan bahwa auditor dengan spesialisasi industri bermanfaat dalam menghalangi kecurangan laporan keuangan dan hal tersebut dipengaruhi oleh ukuran klien (total aset).

\section{HASIL DAN PEMBAHASAN}

\section{Pengaruh Kompetensi (X1), Independensi (X2) dan Ukuran auditee (X3) terhadap Kualitas Audit}

Berdasarkan hasil pengolahan data, maka persamaan regresi dalam penelitian ini adalah:

$\mathrm{Y}=1,089+0,585 \mathrm{X}_{1}+0,277 \mathrm{X}_{2}-1,69 \mathrm{E}-14$

Untuk lebih jelasnya hasil perhitungan regresi ditampilkan pada Tabel

Tabel 1. Hasil Perhitungan Regresi

\begin{tabular}{ccc}
\hline Variabel & $\begin{array}{c}\text { Koefisien } \\
\text { Regresi }\end{array}$ & Signifikansi \\
\hline Kompetensi Auditor & 0,585 & 0,000 \\
Independensi Auditor & 0,277 & 0,003 \\
Ukuran Auditee & $-1,69 \mathrm{E}-14$ & 0,082 \\
\hline Adjusted R square & 0,656 \\
Multiple R & 0,816 \\
Signifikansi & 0,000 \\
F hitung & 70,316 \\
\hline
\end{tabular}

Koefisien regresi variabel menunjukkan dua hal:

1. Menunjukkan besarnya perubahan variabel terikat jika tanpa ada pengaruh variabel bebas.

2. Koefisien regresi menunjukkan arah perubahan antara variabel bebas terhadap variabel terikat.

Koefisien regresi yang bertanda positif menunjukkan perubahan yang searah antara variabel bebas terhadap variabel terikat, sedangkan koefisien regresi yang bertanda negatif menunjukkan arah perubahan yang berlawanan arah antara variabel bebas terhadap variabel terikat. Dalam perhitungan menunjukkan tidak semua variabel bebas memiliki koefisien bertanda positif, makna dari besaran yang ada adalah: 
a. Konstanta (a) sebesar 1,089 menunjukkan kualitas audit apabila variabel bebas bernilai nol.

b. Koefisien regresi kompetensi auditor sebesar 0,585 yang berarti jika kompetensi auditor meningkat, maka kualitas audit juga mengalami peningkatan dan sebaliknya, dengan asumsi variabel bebas lainnya dianggap konstan.

c. Koefisien regresi independensi auditor sebesar 0,277 yang berarti jika independensi auditor meningkat, maka kualitas audit juga mengalami peningkatan dan sebaliknya, dengan asumsi variabel bebas lainnya dianggap konstan.

d. Koefisien regresi ukuran auditee sebesar -1,69E-14 yang berarti jika ukuran auditee meningkat, maka kualitas audit mengalami penurunan dan sebaliknya, dengan asumsi variabel bebas lainnya dianggap konstan.

\section{Uji Validitas}

Validitas adalah suatu derajat ketepatan alat ukur penelitian tentang isi sebenarnya yang diukur. Analisis validitas item bertujuan untuk menguji apakah tiap butir pertanyaan benar-benar telah sahih, paling tidak kita dapat menetapkan derajat yang tinggi dari kedekatan data yang diperoleh dengan apa yang kita yakini dalam pengukuran. Sebagai alat ukur yang digunakan, analisis ini dilakukan dengan cara mengkorelasikan antara skor item dengan skor total item. Hasil uji validitas selengkapnya nampak pada Lampiran 7. Dalam hal ini tidak terdapat koefisien korelasi yang dinilai signifikansinya lebih besar dari 5\% (Sugiono, 1997:70), sehingga itemitem yang bersangkutan sahih sebagai pembentuk indikator dan dikeluarkan dari item pembentuk variabel.

\section{Uji Reliabilitas}

\section{Tabel 2. Uji Reliabilitas}

\begin{tabular}{lcc}
\hline \multicolumn{1}{c}{ Variabel } & Reliabilitas & Ket. \\
\hline Kualitas Audit & 0,8575 & Reliabel \\
Kompetensi Auditor & 0,9364 & Reliabel \\
Independensi Auditor & 0,6538 & Reliabel \\
\hline
\end{tabular}

Sumber: data diolah

Hasil pengujian menunjukkan bahwa nilai cronbach alpha setiap konstruk atau variabel lebih besar dari 0,60 sehingga dapat disimpulkan semua item pada masing-masing variabel reliabel, sehingga data yang ada dapat diproses lebih lanjut. 


\section{Uji Heteroskedastisitas}

Hasil Heteroskedastisitas dalam penelitian ini menggunakan korelasi rank spearman antara residual dengan seluruh variabel bebas dengan hasil analisis sebagai berikut:

\section{Tabel 3. Uji Heteroskedastisitas}

\begin{tabular}{lcccc}
\hline \multicolumn{1}{c}{ Variabel } & Sign & $>/<$ & $\boldsymbol{\alpha}$ & Keterangan \\
\hline Kompetensi Auditor & 0,754 & $>$ & 0,05 & Homo skedastisitas \\
Independensi Auditor & 0,386 & $>$ & 0,05 & Homo skedastisitas \\
Ukuran Auditee & 0,259 & $>$ & 0,05 & Homo skedastisitas \\
\hline
\end{tabular}

Sumber: data diolah

Hasil analisis menunjukkan tidak adanya korelasi antara residual dengan variabel bebasnya (tidak ada yang signifikan), sehingga hasil analisis ini dapat disimpulkan tidak terjadi Heteroskedastisitas.

\section{Uji Multikolinieritas}

Tabel 4. Hasil Multikolinieritas

Sumber: data diolah

\begin{tabular}{lc}
\hline \multicolumn{1}{c}{ Variabel } & VIF \\
\hline Kompetensi Auditor & 1,036 \\
Independensi Auditor & 1,036 \\
Ukuran Auditee & 1,002 \\
\hline
\end{tabular}

Dalam pengujian asumsi klasik terhadap analisis regresi linier berganda menyatakan bahwa penelitian ini tidak terjadi multikolinieritas atau non multikolinieritas, karena nilai VIF dari masing-masing variabel bebas lebih kecil dari 10. jadi dapat disimpulkan bahwa dalam penelitian ini tidak terjadi adanya multikolonieritas (Ordinary Least Square (OLS) tidak dapat ditentukan (indeterminate) dan variance serta standard error-nya tak hingga).

\section{Uji Normalitas}

Tabel 5. Hasil Pengujian Normalitas

\begin{tabular}{lcccc}
\hline \multicolumn{1}{c}{ Variabel } & Sign & $>/<$ & $\boldsymbol{\alpha}$ & Simpulan \\
\hline Kualitas Audit & 0,101 & $>$ & 0,05 & Normal \\
Kompetensi Auditor & 0,103 & $>$ & 0,05 & Normal \\
Independensi Auditor & 0,196 & $>$ & 0,05 & Normal \\
Ukuran auditee & 0,067 & $>$ & 0,05 & Normal \\
\hline
\end{tabular}

Sumber: data diolah 
Hasil normalitas pada tabel 5 menunjukkan bahwa data ketiga variabel penelitian berdistribusi normal, dibuktikan dengan nilai signifikan variabel kualitas auditor, kompetensi auditor dan ukuran auditee lebih dari 0,05. Pengujian yang dilakukan pada model yang dihasilkan tidak terdapat pelanggaran asumsi klasik yaitu: Non Heteroskedastisitas, Non Autokorelasi dan Normalitas sehingga model tersebut valid sebagai estimator.

\section{Pengujian Secara Simultan}

\section{Kriteria Hipotesis}

$\mathrm{H}_{0}: \mathrm{b}_{1}=\mathrm{b}_{2}=0$, secara bersama-sama kompetensi auditor, independensi auditor dan ukuran auditee tidak berpengaruh terhadap kualitas audit.

$\mathrm{H}_{\mathrm{a}}$ : salah satu dari $\mathrm{b}_{\mathrm{i}} \neq 0$ secara bersama-sama kompetensi auditor, independensi auditor dan ukuran auditee berpengaruh terhadap kualitas audit.

Level of significant yang dipergunakan dalam penelitian adalah 5\%, sehingga dapat dikatakan bahwa penelitian memiliki tingkat kesalahan sebesar 5\%, sedang keakuratan data yang dipergunakan adalah sampai dengan $95 \%$. Derajat kebebasan dalam penelitian antara lain (k, n-k-1) yaitu sebesar (106).

Pada tingkat signifikansi 0,05 dan derajat kebebasan sebesar 3 dan 106, maka diperoleh $F_{\text {tabel }}$ sebesar 2,68. Nilai $F_{\text {hitung }}$ berdasarkan perhitungan sebesar 70,316 dan tingkat signifikansi sebesar $0,000<$ dari level of signifikan yang digunakan yaitu 0,05 . Dapat disimpulkan bahwa secara simultan kompetensi auditor, independensi auditor dan ukuran auditee berpengaruh signifikan terhadap kualitas audit.

\section{Pengujian Secara Parsial}

Uji statistik t digunakan untuk mengetahui apakah variabel bebas yang dimasukkan dalam model secara parsial berpengaruh signifikan terhadap variabel terikat. Metode yang digunakan adalah dengan membandingkan nilai $t_{\text {hitung }}$ dengan $t_{\text {tabel }}$. Nilai $\mathrm{t}_{\text {tabel }}$ didapat dengan memperhatikan jumlah observasi atau pengamatan $(\mathrm{n}=$ 110) dan derajat kebebasan (n-k-1), sehingga derajat kebebasan didapat (110-3-1) $=(\mathrm{df}=106)$ dan menggunakan level of significant $(\alpha=0,05)$. Hasil pengujian secara parsial selengkapnya nampak pada Tabel.

Tabel 6. Hasil Uji Parsial

\begin{tabular}{lcc}
\hline \multicolumn{1}{c}{ Variabel Bebas } & Signifikansi & Kesimpulan \\
\hline Kompetensi Auditor & 0,000 & Signifikan \\
Independensi Auditor & 0,003 & Signifikan \\
Ukuran Auditee & 0,082 & Tidak Signifikan \\
\hline
\end{tabular}

Sumber: data diolah 


\section{Pengujian Hipotesis H1}

\section{Kriteria Hipotesis}

$\mathrm{H}_{0}: \mathrm{b}_{1}=0$, Kompetensi auditor tidak berpengaruh terhadap kualitas audit.

$\mathrm{H}_{\mathrm{a}}: \mathrm{b}_{1} \neq 0$, Kompetensi auditor berpengaruh terhadap kualitas audit.

\section{Pengujian Hipotesis $\mathrm{H} 2$}

\section{Kriteria Hipotesis}

$\mathrm{H}_{0}: \mathrm{b}_{2}=0$, Independensi auditor tidak berpengaruh terhadap kualitas audit

$\mathrm{H}_{\mathrm{a}}: \mathrm{b}_{2} \neq 0$, Independensi auditor berpengaruh terhadap kualitas audit

\section{Pengujian Hipotesis H3}

\section{Kriteria Hipotesis}

$\mathrm{H}_{0}: \mathrm{b}_{2}=0$, Ukuran auditee tidak berpengaruh terhadap kualitas audit

$\mathrm{H}_{\mathrm{a}}: \mathrm{b}_{2} \neq 0$, Ukuran auditee berpengaruh terhadap kualitas audit

\section{Koefisien Determinasi Total}

Untuk mengetahui kemampuan variabel bebas dalam menerangkan atau menjelaskan perubahan variabel terikat dapat dilihat dari nilai koefisien determinasi (adjusted $\mathrm{R}^{2}$ ). Nilai dari adjusted $\mathrm{R}^{2}$ berkisar antara 0 sampai 1 , semakin mendekati 1 maka semakin baik kemampuan variabel bebas dalam menjelaskan variabel terikat dalam model. Nilai dari koefisien determinasi dari hasil perhitungan sebesar 0,656. Hal ini berarti 65,6\% perubahan kualitas audit mampu dijelaskan oleh kompetensi auditor, independensi auditor dan ukuran auditee secara bersama-sama, sedangkan sisanya $34,4 \%$ dijelaskan oleh variabel lain yang tidak dimasukkan dalam model (faktor galat).

\section{PEMBAHASAN}

Hasil pengujian pada penelitian ini menunjukkan bahwa kompetensi auditor, independensi auditor dan ukuran auditee secara simultan berpengaruh terhadap kualitas audit. Hal ini berarti bahwa kualitas audit akan meningkat jika auditor memiliki kompetensi yang baik dan didukung dengan sikap independensinya serta ukuran auditee. Hasil pengujian secara parsial menunjukkan kompetensi mempengaruhi kualitas audit, independensi mempengaruhi kualitas audit dan ukuran auditee tidak mempengaruhi kualitas audit. 


\section{Pengaruh Kompetensi terhadap Kualitas Audit}

Kompetensi auditor berpengaruh terhadap kualitas audit, di mana hal ini telah sesuai dengan hipotesis pertama bahwa kompetensi berpengaruh terhadap kualitas audit. Kualitas audit dapat dicapai jika auditor memiliki kompetensi yang baik. Kompetensi tersebut terdiri dari kepemimpinan, profesionalisme dan pengetahuan terkait profesi. Kepemimpinan menyangkut kepemimpinan strategis dan organisasional, efektivitas organisasi, kepemimpinan individu dan tim serta pengembangannya. Profesionalisme dalam hal etika dan kepercayaan, fokus pada stakeholders, komunikasi, pendekatan menyeluruh, pemecahan masalah, pengembangan profesi, evaluasi diri secara profesional. Pengetahuan terkait profesi yang harus dikuasai oleh auditor adalah akuntansi keuangan dan pelaporan, akuntansi manajemen, keyakinan dan jasa lain yang terkait, keuangan dan perencanaan keuangan, lingkungan bisnis, teknologi informasi dan perpajakan. Auditor sebagai pelaksana tugas audit harus senantiasa meningkatkan kompetensi yang telah dimiliki agar dapat menerapkan pengetahuan secara maksimal dalam pelaksanaan tugasnya.

Hasil penelitian ini mendukung penelitian yang dilakukan oleh De Angelo (1981) dan Deis dan Groux (1992) menjelaskan bahwa probabilitas untuk menemukan pelanggaran atas sistem akuntansi klien (kualitas audit) tergantung pada kemampuan teknis auditor. Penelitian ini juga mendukung penelitian Mayangsari (2003), Putri (2010), Sukriah (2010) dan Alim (2007) yang menunjukkan kompetensi berpengaruh terhadap kualitas audit. Semakin baik kompetensi seorang auditor maka kualitas audit yang dihasilkan akan semakin baik pula.

\section{Pengaruh Independensi terhadap Kualitas Audit}

Independensi auditor berpengaruh terhadap kualitas audit, di mana hal ini telah sesuai dengan hipotesis kedua. Independensi tersebut diukur melalui lama hubungan dengan auditee dan pemberian jasa non audit, tekanan dari auditee serta telaah dari rekan auditor. Tekanan dapat berupa pemberian sanksi dan ancaman pergantian auditor, fasilitas dari auditee. Telaah dari rekan auditor juga dapat meningkatkan independensi (Deis dan Giroux, 1992) disamping sebagai konsekuensi atas audit yang dilakukannya. Independensi tersebut menunjukkan semakin lama hubungan dengan auditee, hal tersebut tidak mempengaruhi independensi auditor, tetapi lebih baik seorang auditor melakukan pemeriksaan pada entitas tertentu maksimal 3 tahun. Begitupula dengan tekanan dari auditee dan jasa non audit yang diberikan oleh auditor kepada auditee tidak mempengaruhi independensinya pada saat melakukan pemeriksaan. Telaah dari rekan auditor dapat meningkatkan independensi seorang auditor.

Penelitian ini mendukung penelitian Elitzur, et al. (1996) yang menunjukkan kualitas audit akan meningkat jika independensi meningkat. Begitupula dengan penelitian Wooten (2003) dalam Alim, et al. (2007) yang menunjukkan independensi berpengaruh signifikan terhadap kualitas audit dalam sektor privat. 
Dalam sektor Publik, penelitian ini mendukung penelitian yang dilakukan oleh Wati, et al. (2010) yang menyebutkan independensi berpengaruh terhadap kinerja auditor pemerintah, tetapi tidak mendukung penelitian yang dilakukan oleh Mabruri \& Jaka (2010) dan Sukriah, et al. (2010) yang menunjukkan independensi tidak berpengaruh secara signifikan terhadap kualitas hasil audit/ pemeriksaan di lingkungan pemerintah daerah.

\section{Pengaruh Ukuran Auditee terhadap Kualitas Audit}

Hasil pengujian membuktikan bahwa ukuran auditee tidak berpengaruh terhadap kualitas audit, dimana hal ini tidak sesuai dengan hipotesis ketiga bahwa ukuran auditee berpengaruh terhadap kualitas audit. Hal ini menunjukkan dalam sektor publik, total aset dan pendapatan asli daerah tidak mempengaruhi kualitas audit laporan keuangan yang dimiliki oleh seorang auditor. Hal ini disebabkan sektor publik/pemerintahan memiliki total aset dan nilai pendapatan yang hampir sama di seluruh Jawa, sehingga kesamaan tersebut tidak mempengaruhi kualitas yang dicapai oleh auditor. Ukuran auditee tidak mempengaruhi kualitas audit seorang auditor karena tanggungjawab auditor adalah melakukan pemeriksaan baik ukuran auditee tersebut besar atau kecil, hal ini tidak mempengaruhi sikap auditor dalam bertindak dan mengambil kebijakan pada saat pemeriksaan. Kualitas audit berdasarkan hasil penelitian hanya berdasarkan kompetensi dan independensi yang dimiliki auditor, tidak dipengaruhi faktor auditee.

Penelitian ini tidak mendukung penelitian yang dilakukan oleh Carcello, dkk. (2004) dan Deis \& Giroux (1992) yang menunjukkan bahwa auditor dengan spesialisasi industri bermanfaat dalam menghalangi kecurangan laporan keuangan dan hal tersebut dipengaruhi oleh ukuran klien (total aset). Carcello, dkk. (2004) menyebutkan penelitian lebih jauh menyimpulkan klien yang lebih besar mempunyai kemampuan menawar yang lebih besar dan lebih meyakinkan bagi auditor untuk penggunaan akuntansi. Auditor yang memiliki kemampuan lebih baik terutama yang memiliki spesialisasi industri bermanfaat dalam menghalangi kecurangan klien, terdapat hubungan negatif antara spesialisasi industri auditor dan kecurangan keuangan klien dan hubungan tersebut lebih lemah untuk klien yang lebih besar. Penelitian kualitas audit laporan keuangan pada sektor publik tidak menggunakan faktor spesialisasi industri bagi auditor, tetapi kemampuan auditor secara umum sehingga dalam penelitian ini kualitas audit auditor tidak dipengaruhi ukuran klien.

Dalam sektor privat, klien yang mempunyai keuangan lebih bagus memiliki profitabilitas tinggi dan cenderung tidak memiliki kegagalan keuangan, sehingga cenderung tidak mempengaruhi auditor dalam pelaksanaan pemeriksaan. Dalam situasi tersebut, auditor menjadi puas dan kurang rajin dalam melakukan audit (Knapp, 1985). Kontrak audit besar, klien lebih bagus secara financial, tidak selalu terkait dengan kualitas audit yang buruk, namun potensi untuk kepuasan di sisi 
auditor dan kekuasaan yang dilaksanakan oleh klien tersebut mempertinggi kecenderungan mutu audit lebih rendah. Pada sektor publik, kotrak audit tidak tergantung pada klien yang mempunyai keuangan besar atau kecil, tetapi pelaksanaan audit dilakukan karena adanya kewajiban pelaksanaan pemeriksaan atas keuangan Negara. Semua entitas yang menggunakan keuangan Negara memiliki kewajiban untuk diaudit oleh BPK RI, hal ini menyebabkan ukuran auditee tidak mempengaruhi kualitas audit.

\section{SIMPULAN}

Berdasarkan hasil analisis, diperoleh kesimpulan bahwa hipotesis pertama dan kedua diterima yaitu kompetensi dan independensi auditor sektor publik memiliki pengaruh terhadap kualitas audit laporan keuangan, sedangkan hipotesis ketiga tidak diterima yaitu ukuran auditee tidak mempengaruhi kualitas audit yang dimiliki auditor.

Kompetensi auditor sektor publik memiliki pengaruh terhadap kualitas audit laporan keuangan. Kompetensi kepemimpinan ini dapat dilihat dari tiga indikator perilaku yaitu kepemimpinan strategis dan organisasional, efektivitas organisasi, kepemimpinan individu dan tim. Ciri utama dari profesi akuntan adalah komitmen dari akuntan untuk memegang standar etika dan profesional tertinggi. Akuntan disyaratkan menerapkan integritas, objektivitas, independensi, dan pertimbangan profesional dalam berbagai aspek pekerjaannya. Mereka mempertahankan profesionalisme dengan cara bersikap inovatif, mengambil inisiatif, mengelola harapan dari klien dan stakeholder (pemangku kepentingan), mengaplikasikan pendekatan yang menyeluruh untuk penyelesaian masalah dan berkomitmen untuk terus-menerus mengembangkan diri. Indikator dari profesionalisme ini terdiri dari etika dan kepercayaan, fokus pada stakeholders, komunikasi, pendekatan menyeluruh, pemecahan masalah, pengembangan profesi, dan evaluasi diri. Pengetahuan terkait profesi menjamin akuntan mampu menganalisis dan menyampaikan informasi keuangan yang jelas, transparan dan andal. Dan yang paling penting adalah mengembangkan strategi bisnis yang sukses berbasis informasi keuangan. Pengetahuan profesional ini mencakup akuntansi keuangan dan pelaporan, akuntansi manajemen, pemberian keyakinan dan jasa lain yang terkait, perencanaan keuangan, lingkungan bisnis, teknologi informasi dan perpajakan.

Independensi auditor dapat mempengaruhi kualitas audit. Independensi ini terdiri dari tekanan auditee, telaah dari rekan auditor, lamanya hubungan dengan auditee dan pemberian jasa selain audit. Tekanan dari auditee dapat berupa pemberian sanksi dan ancaman pergantian auditor, fasilitas dari auditee. Telaah dari rekan auditor juga dapat meningkatkan independensi disamping sebagai konsekuensi atas audit yang dilakukannya. Penelitian ini tidak dapat membuktikan hipotesis ketiga yaitu ukuran auditee tidak memiliki pengaruh terhadap kualitas audit laporan 
keuangan. Hal ini disebabkan sektor publik/pemerintahan memiliki total aset dan nilai pendapatan yang hampir sama di seluruh Jawa, sehingga kesamaan tersebut tidak mempengaruhi kualitas yang dicapai oleh auditor. Selain itu, kualitas audit auditor dituntut tetap terjaga, baik dengan nilai aset dan pendapatan yang tinggi ataupun rendah.

\section{DAFTAR PUSTAKA}

Alim, N., dan Trisni, H., Liliek, P. 2007. Pengaruh Kompetensi dan Independensi terhadap Kualitas Audit dengan Etika Auditor sebagai Variabel Moderasi. Simposium Nasional Akuntansi X, Makasar.

Bonner, S.E. 1990. Experience Effects in Auditing: The Role of Task-Specific Knowledge. The Accounting Review. Vol. 65 No. 1 Pg 72-92.

Carcello, Joseph, V., dan Albert, L.N. 2004. Client Size, Auditor Specialization, and Fraudulent Financial Reporting. Managerial Auditing Journal. Vol 19, Iss. 5. Pg 651.

Deis, Donald, R. Jr dan Gary, A.G. 1992. Determinants of Audit Quality in the Public Sector. The Accounting Review, Vol 67, No.3.

Elitzur, R., dan Haim, F. 1996. Planned Audit Quality. Journal of Accounting and Public Policy. Vol.15, Pg. 247-269.

Holt, O. 2007. Audit Quality Framework Outlined As FRC Publishes Response to DP. Accountancy Ireland. Dublin: Dec 2007. Vol. 39, Iss. 6; pg. 24, 4 pgs.

Maradona, A., dan Sutrisno, Grahita, C. Tenur Auditor dan Kualitas Audit: Suatu Pembuktian bagi Kewajiban Rotasi Auditor di Indonesia.

Mayangsari, S. 2003. Pengaruh Keahlian Audit dan Independensi terhadap Pendapat Audit: Sebuah Kuasieksperimen. Jurnal Riset Akuntansi Indonesia Vol 6, hal 1-22.

Mautz, R.K., dan H.A. Sharaf. 1961. The Philosophy of Auditing. Sarasota, Florida: American Accounting Association

Putri, N.E. 2010. Pengaruh Kompetensi dan Etika Profesi terhadap Kualitas Audit Laporan Keuangan dengan Tipe Kepribadian sebagai Variabel Pemoderasi. Tesis. Program Pascasarjana Magister Akuntansi Universitas Padjajaran. Bandung.

Shockley, R.A.1982. Perceptions of Audit Independence: A Conceptual Model. Journal of Accounting, Auditing \& Finance 5 (Winter)

Sukriah, A., dan Inapty. 2010. Pengaruh Pengalaman Kerja, Independensi, Obyektifitas, Integritas dan Kompetensi terhadap Kualitas Hasil Pemeriksaan. Simposium Nasional Akuntansi XIII. Purwokerto

Tan, H.T., dan Alison, K. 1999. Accountability Effect on Auditor's Performance: The Influence of Knowledge, Problem Solving Ability, and Task Complexity. Journal of Accounting Research. Vol. 37 No 1 Spring. 